\title{
DOUBLE DIP PANDEMIC IMPACT ON PORTFOLIO OF INVESTORS REFERENCE TO SALARIED EMPLOYEES
}

\author{
P. Madhu Kumar Reddy \\ Research Scholar \\ Department of Business Management \\ KL Business School \\ Koneru Lakshmaiah Education Foundation (Deemed to be University) \\ Vaddeswaram, Guntur District, India \\ E-mail: madhukumarreddy@gmail.com \\ (iD https://orcid.org/0000-0002-2750-2604 \\ Dr. V S Prasad Kandi \\ Assistant Professor \\ Department of Business Management \\ KL Business School \\ Koneru Lakshmaiah Education Foundation (Deemed to be University) \\ Vaddeswaram, Guntur District, India \\ E-mail: kandi.vsp@gamil.com \\ (iD) https://orcid.org/0000-0002-9346-8192 \\ Dr. A. Rama Kumar \\ Former Professor \\ Department of Business Management \\ KL Business School \\ Koneru Lakshmaiah Education Foundation (Deemed to be University) \\ Vaddeswaram, Guntur District, India \\ E-mail: ark6466@gmail.com \\ iD https://orcid.org/0000-0002-9829-3176
}

Received: November 17, 2021 Accepted: January 04, 2022 Online Published: February 05, 2022

DOI: $10.46281 /$ ijfb.v9i1.1589

URL: https://doi.org/10.46281/ijfb.v9i1.1589

\begin{abstract}
The ongoing health crisis around COVID-19 has affected all communities. The Government has taken action since the Coronavirus attack created an unprecedented situation. Drop-down COVID-19 positive cases in December and January made people to normal life. An immediate double-dip from the COVID19, plow back them into hazardous life with more effective and more quickly spreading of virus leads to the second lockdown. The present study analyzed different investments avenues and the factors that affect the investment. The main objective of the study is to know the relationship between the re-entry of COVID-19 and the change in investment decisions of the salaried employees in Telangana. The study also identifies the investor's attitude towards Mutual Funds and understands how the second wave
\end{abstract}


COVID-19 has impacted on investments and financial decisions of individuals in developing nations such as India.

Keywords: Savings, Investment Avenues, Pandemic, Weighted Aspects, Portfolio Construction.

JEL Classification Codes: G01, G11, G40, G41, G51.

\section{INTRODUCTION}

COVID -19, Novel Corona virus Disease, highly infectious significantly disrupted human life. Government suggested several measures to fight against this pandemic situation like social distancing, self-distancing, and self-isolation, cease of educational institutions, transportation restrictions, and nationwide lockdown. On $30^{\text {th }}$ January 2020 the first Covid-19 positive case was registered in India. Gradually cases have increase regularly, with this effect from $25^{\text {th }}$ March 2020, the Government of India declared a 3 week country wide lockdown. On an average every day, India recorded 35,000 new cases by the end of October and up to the month of January 2021 slowly number of positive cases decrease. But on $10^{\text {th }}$ February, India confirmed 11,000 positive cases prior as second wave, and within two months it reaches to 89,800 cases that lead to lockdown from $12^{\text {th }}$ May to $31^{\text {st }}$ May 2021. Distribution of vaccination like Covisheld and covaxin creates hopes and fill the will power to fight against this devil virus.

Due to this protracted lockdown and restricted economy activity, the economy witnessed as an extended period of slow down and financial crisis, many of the people lost jobs, collapse of the business. The economy had paid the major effects on Gold price, Market indices, Crude oil and Crypto Currencies with the impact of second wave COVID -19. The present survey based study attempts to analyze the investor preference, factors influencing for investment.

\section{REVIEW OF LITERATURE}

Gurbaxani and Gupte (2021) highlighted the results on impact of COVID-19 on individual investor behavior with a decline of $43 \%$ in the SIP investment was common to the genders but vary with age and COVID19 outbreak at micro-level and may enhance the financial institution and individuals for handling in situation better in future. An economy incident a supply and demand of output and employment with the pandemic impact in terms of magnitude and intensity in short run, (Afrina et al., 2021), the pandemic and market volatility caused a sharp down in resources, business sector, financial institutions that threaten more than the virus throughout the global community. Investor's perception in volatility and return in between India's Implied Volatility Index (IVIX) and Nifty 50 during COVID-19 pandemic, (Chittineni, 2020), garbing the opportunity at market decline to invest and to sell as market raise based on the fundamental market movements that effects for the IVIX futures in India. Along with global capital market, Indian Mutual Fund industry crisis during pandemic, like Franklin Templeton debt funds forced wind up. With a certain new compliances and regulation by SEBI, to ally the pain of investors strengthen and focused on the investment goals ( Polisetty, 2020) Indian Mutual Funds during COVID pandemic times). NAV's of various schemes of Mutual Fund schemes like HSBC Large Cap Equity Fund, LIC Mutual Fund, Canara Robeco Blue chip Equity Fund and BNP Paribas Large Cap Fund performance are satisfied with the majority of the investors at pre COVID-19 (Manoj \& Avinash, 2020), the index funds of all the scheme are gradually decrease with the outbreak of COVID-19. Investors risk bearing capacity with neuroticism, agreeableness, extraversion and conscientiousness are influenced by the various demographical factor and personal traits (Athira \& Kakkakunnan, 2020), result accompany with the summary of Dhiman and Raheja (2018) and (THOMAS \& RAJENDRAN, n.d.), present risk bearing capacity, proper investment decision and beneficiary situation for the financial institutions to offer best financial product and provide correct guidance about investment avenues. Bounded knowledge, nature, self-control and limitations of the investors differ in investment pattern (Sendilvelu $\&$ Shah, 2021), fund managers and financial advisors involved in market analysis and sensitivity to assist Start -up Entrepreneur and Self Employed in investment pattern to occupy perspective gain in future. COVID-19 has footprint the financial crisis, health crisis were influenced on the investors perception in 
various investment avenues in pre and during of pandemic (Mushir \& Suryavanshi, 2021), results shows the change in the preference of the investment pattern like risk free stock, insurance, gold, bank deposits and PPF with enhancing effective strategies in portfolio allocation in present crisis. A dread in global market, blow in mutual fund and descend in international oil prices begins in 2020 (Polisetty \& Manda, 2020 ) Indian Mutual Funds in the times of Covid-19 Introduction). ( Srivastava \& Kulshrestha, 2020), stick to the (Graham \& Dodd, 1996), "stock is not just a ticker symbol or an electronic blip; it is an ownership interest in an actual business, with an underlying value that does not depend on its share price", investing technique results in Indian stock market (Nifty), and International stock market (Dow Jones).

\section{Household Incomes and Investment Avenues}

Due to the COVID 19, an Indian household income was terrifically impact during lockdown on April 12,2020 . An outstanding decline in the level of income with household reporting to a fall about 9 percent in tardy February to 45.7 percent massive in mid-April (STATISTA, 2021). The outbreak of COVID19, gives a significant impact on the income towards real estates and equity (Khan et al., 2020). Agrawal and Ashraf (2020) band together with Dvara Research explore on the daily life of low income households highlighted that effective access for the eligible beneficiaries, raising transactions failures immediately, developing a transparent system. The entry of COVID-19, created an industrial recession that change the perception of the Indian citizens about income, savings and spending (Jain, n.d.). An extraordinary assist requires for the economy from monetary policy (Schembri, 2021), estimated that pandemic "forced and precautionary" saving added about $\$ 180$ billion because Canadians are unable to spend on going out, entertainment, travelling, but more cautious about health and finance.

\section{Weighted Aspects}

Based on the psychological theories (THOMAS \& RAJENDRAN, n.d.), (personality and investor behavior influence the investment pattern of the various investment avenue and its benefit aspect. Investment motives and investors personal characteristics gives an significant impact on the investment preferences (Riyazahmed, 2021), analyzed a wide range of investment factors that knowledge about Mutual Fund and market more influence the investment preferences than the investment motives. An effective financial decision for Start-Up-Entrepreneur and Self Employed are differ (Sendilvelu \& Shah, 2021) observed their investment pattern aid fund manager, financial institution and other investors for market analysis.

\section{Income Level and Savings}

An activity was engaged by the people who have savings i.e. investment that are made. A true and famous quote by Buffett (n.d.), "Don't save what is left after spending; spend what is left after saving". It has become famous in today's high competitive and risky market. According to SRD (Neill, 2021), Dec 2020, around 1500.07 (000's) were fresh graduates and PG, join their dream job get salary and feel that moment got success. Gradually when time passed raised a question about their hard earn money and savings. The two strongest pillar of economy savings and investment had yacht in this pandemic highlighted once again the tradition and importance of saving to all categories investors in India. A significant drop in the household income and savings during this crisis and average one year at least to recovery (Martin et al., 2020).

\section{HYPOTHESIS OF THE STUDY}

- Hypothesis $1\left(\mathrm{H}_{1} \mathrm{~A}\right)$ : Second wave of COVID-19 has an impact on the preference of the investors in investment.

- Hypothesis $2\left(\mathrm{H}_{1} \mathrm{~B}\right)$ : COVID-19 second wave has an impact on the weighted aspects of the investors in investment.

- Hypothesis $3\left(\mathrm{H}_{1} \mathrm{C}\right)$ : The savings of the investors differs in constructing portfolio in first and second wave of COVID-19. 


\section{RESEARCH METHODOLOGY}

Based on the systematic method of data collection and analysis the validity of any research is justifiable. In this research paper, an attempt has made by authors to evaluate the impact of reentry of COVID-19 on the portfolio of the investors special emphasis on salaried employees with a sample of 115 from March $18^{\text {th }} 2021$ to $17^{\text {th }}$ May 2021.

\section{Research Design}

Over 156 questionnaires were circulated, $115(74 \%)$ were considered for the final research work. It is well known fact that the demographic data are the sources and the principle means for gathering the basic and social statistics of the individuals and also influence the standard of living, economy growth, consumption, savings, and investment etc. of the individuals. The present study questionnaire has two major parts. The first part had five dimensions with respect to the demographical profile of the respondents; second part had 17 dimensions, includes three variables such as investment avenues, weighted aspects, and income level and savings. Six dimensions were used to assess the of the preference of investment in pre and second wave of COVID-19 with respect to the portfolio construction, added to these lines seven dimensions to the weighted aspects to measure the benefits from the various investment avenues, and followed to this four dimensions of the savings of the respondents to quantify the factors influence in investment alternative. Each variable consist of different dimensions that help to analyze the preference of the Indian investors respondents in constructing the portfolio (see table 1).

Table 1. Variable construct and source

\begin{tabular}{|l|l|l|}
\hline S.no & Variables & Items \\
\hline 1 & Investment avenues & 6 \\
\hline 2 & Weighted aspects & 7 \\
\hline 3 & Saving & 4 \\
\hline
\end{tabular}

Note: V- variables to construct the preference, benefits and income of the investors.

\section{Sample Size}

According to the steps taken by the Government to fight against the pandemic, primary data was collected through structured questionnaire to determine the impact of second wave of COVID-19 on investors, communicated with respondents in the form of telephone survey method administered to a purposive and convenience sample of 115 Indian respondents to evaluate the hypothesized relationship. By using Yamane's Formula (1967), researchers draw a sample size of 115 Indian respondents with 5\% level of significance.

Formula:

$\mathrm{n}=\mathrm{N} / 1+\mathrm{N}(\mathrm{e}) / 2$

$\mathrm{n}=$ Sample size

$\mathrm{N}=$ total number circulated/ observation in area

$\mathrm{e}=$ precision value/ level of significance

\section{Statistical Tools}

Research data was analyzed with

- Descriptive analysis

- Standard deviation

- Standard error

- Pearson correlation

- Test of homogeneity

- Analysis of variance (ANOVA) with the help of SPSS 
$\mathrm{Df}=(\mathrm{k}-1),(\mathrm{n}-\mathrm{k}),(\mathrm{n}-1)$

$\mathrm{MSC}=\mathrm{SSC} / \mathrm{k}-1$

$\mathrm{MSE}=\mathrm{SSE} / \mathrm{n}-\mathrm{k}$

F-ratio=MSC/MSE

Df- degree of freedom

MSC- mean of sum of square

MSE- mean of square within a sample

$F$ ratio- $f$ calculated value/ $f$ significant value

\section{Results}

- If $\mathrm{F}$ calculated value is $<\mathrm{F}$ tabulation value accept null hypothesis

$$
\text { F cal }<\mathrm{ftab}=\text { accept } \mathrm{H}_{0}
$$

- If $\mathrm{F}$ calculated value is $>\mathrm{F}$ tabulation value accept alternative hypothesis

$$
\text { F cal }>\mathrm{f} \mathrm{tab}=\text { accept } \mathrm{H}_{1}
$$

RESULT AND DISCUSSION

\begin{tabular}{|c|c|c|c|c|}
\hline SL. & Respondents particulars & & No of respondents & Valid percent \\
\hline & \multirow[t]{2}{*}{ Gender } & Male & 78 & 67.82 \\
\hline & & Female & 37 & 32.17 \\
\hline & \multirow[t]{4}{*}{ Age } & Upto 30 years & 5 & 4.34 \\
\hline & & $31-40$ years & 71 & 61.73 \\
\hline & & $41-50$ years & 32 & 27.82 \\
\hline & & Above 50 years & 7 & 6.05 \\
\hline & \multirow[t]{4}{*}{ Education qualification } & Intermediate & - & - \\
\hline & & Graduate & 19 & 16.52 \\
\hline & & Post Graduate & 62 & 53.91 \\
\hline & & Professionals & 34 & 29.56 \\
\hline & \multirow[t]{4}{*}{ Occupation } & $\begin{array}{l}\text { Private } \\
\text { employee }\end{array}$ & 79 & 68.69 \\
\hline & & $\begin{array}{l}\text { Public } \\
\text { employee }\end{array}$ & 28 & 24.34 \\
\hline & & Self employed & 2 & 1.73 \\
\hline & & Others & - & - \\
\hline & \multirow[t]{5}{*}{ Monthly income } & Below 20,000 & 12 & 10.43 \\
\hline & & $20,001-30,000$ & 68 & 59.13 \\
\hline & & $30,001-40,000$ & 29 & 25.21 \\
\hline & & $40,001-50,000$ & 6 & 5.21 \\
\hline & & Above 50,000 & - & - \\
\hline
\end{tabular}

Table 2. Tabular representation of Profile of the Sample Investors Respondents

Source: Primary Data

As per the total population, the sample $(n=115,74 \%)$ was $67.82 \%(n=78)$ male and $32.17 \%$ $(\mathrm{n}=37)$ female, with $61.73 \%(\mathrm{n}=71)$ majority of respondents were under the age of 31-40 years, similarly $27.82 \%(n=32)$ were aged between $41-50$ years, $6.05 \%(n=7)$ of them were above 50 years and $4.34 \%$ $(n=5)$ were up to the age of 30 years. Likewise $16.52 \%(n=19)$ has a degree, $53.91 \%(n=62)$ ere postgraduates and $29.56 \%(n=34)$ are professionals; $68.69 \%(n=79)$ the majority were private employees, 
$24.34 \%(n=28)$ were public employees and $1.73 \%(n=2)$ were self-employed. Along with majority of the respondents reported with monthly income $59.13 \%(\mathrm{n}=68)$ earned 20,001-30,000, 25.31\% $(\mathrm{n}=29)$ yields 30,001-40,000, 10.43\% $(\mathrm{n}=12)$ earned below 20,000 and 5.21\% ( $\mathrm{n}=6)$ earned 40,001-50,000. Among the total sample $(\mathrm{n}=115), 16.52 \%(\mathrm{n}=19)$ were aggressive investors, $31.30 \%(\mathrm{n}=36)$ were conservative investors, $45.21 \%(n=52)$ were balanced investors and $6.95 \%(n=8)$ were speculative investors.

Table 3. Tabular representation of had income level still remains same in first and second wave of COVID-19?

\begin{tabular}{|l|l|l|}
\hline Investors response & No of respondents & Valid Percent \\
\hline Yes & 36 & 31.30 \\
\hline No & 79 & 68.69 \\
\hline Total & $\mathbf{1 1 5}$ & \\
\hline
\end{tabular}

Source: Primary Data

The above table no 3 explains the frequency distribution of the sample investors respondents on the basis of the income level of the investors in between $1^{\text {st }}$ and $2^{\text {nd }}$ wave effect of COVID-19. This shows the analysis of the present study where during pandemic situation; there is a lot of variation in the income of the respondents forming a mean of (68.69) percent with a sample of 79 respondents among 115 respondents.

Table 4. Tabular representation of is there any change in portfolio Re-entry of COVID-19?

\begin{tabular}{|l|l|l|}
\hline Investors response & No of respondents & Valid Percent \\
\hline Yes & 86 & 74.78 \\
\hline No & 29 & 25.21 \\
\hline Total & $\mathbf{1 1 5}$ & \\
\hline
\end{tabular}

Source: Primary Data

The above table exhibits the change in constructing the portfolio of the sample investors' respondents with the re-emerged of COVID-19. With the help of frequency distribution it is clearly shows the result that among 115 sample respondents, majority of the sample that is 76 respondents where forming a mean of (74.58) percent are agreed that there is a change in their portfolio with the second wave of Covid-19. This pandemic not only creates a huge financial and health crisis, but also a severe impact on the income of the individuals that influence their savings in constructing the portfolio.

Table 5. Tabular representation of percentage of income saves during second wave of COVID-19.

\begin{tabular}{|l|l|l|}
\hline Percentage & No of respondent & Valid Percent \\
\hline $11 \%-15 \%$ & 79 & 68.69 \\
\hline $16 \%-20 \%$ & 22 & 19.13 \\
\hline $21 \%-25 \%$ & 14 & 12.17 \\
\hline $26 \%-30 \%$ & - & - \\
\hline Total & $\mathbf{1 1 5}$ & \\
\hline
\end{tabular}

Source: Primary Data

In the above table, it is observed about the percentage of the income of the investors saving for various investment avenues. The percentage of the savings is divided into four levels that are from $11 \%$ to $15 \%, 16 \%$ to $20 \%, 21 \%$ to $25 \%$, and $26 \%$ to $30 \%$. The above table no 5 conclude that nearly 79 sample investors respondents are saving in between $10 \%$ to $15 \%$ forming a mean of( 68.69) percent, 22 
respondents are saving $16 \%$ to $20 \%$ with a valid percent of (19.13) and the remaining are saving $21 \%$ to $25 \%$ of their savings and forming a mean of (12.17) percent in constructing their portfolio.

Table 6. Tabular representation of investment avenues weighted aspect during second wave of pandemic-II.

\begin{tabular}{|l|l|l|}
\hline Weighted aspects & No of respondents & Valid Percent \\
\hline Regular returns & 34 & 29.56 \\
\hline Future security & 26 & 22.60 \\
\hline Liquidity & 22 & 19.13 \\
\hline Children carrier & 17 & 14.78 \\
\hline Retirement & 2 & 1.73 \\
\hline Insurance & 12 & 10.43 \\
\hline Tax benefits & 3 & 2.60 \\
\hline Total & $\mathbf{1 1 5}$ & \\
\hline
\end{tabular}

Source: Primary Data

The main aim of any investors is to constructing their investment portfolio with maximum profit with a minimum risk. The above table shows the analysis of the investors in investing various investment avenues based on the various weighted aspects from their portfolio. It is observed that among 115 sample investors respondents, 34 respondents are looking for the regular returns with a valid mean of (29.56) percent, 26 respondents are investing for future security purpose forming a mean of (22.60) percent, 22 respondents are concentrated on the market liquidity of (19.13) valid percent, and the remaining sample respondents are for other aspects like children carrier, retirement planning, insurance and tax benefits.

Table 7. Tabular representation of preference of investment avenues pre COVID 19

\begin{tabular}{|l|l|l|}
\hline Investment avenues & No of respondents & Valid Percent \\
\hline Bank deposits & 19 & 16.52 \\
\hline Post office & 17 & 14.78 \\
\hline Mutual Funds & 36 & 31.30 \\
\hline Equity & 31 & 26.95 \\
\hline Gold & 8 & 6.95 \\
\hline Insurance & 4 & 3.47 \\
\hline Total & $\mathbf{1 1 5}$ & \\
\hline
\end{tabular}

Source: Primary Data

Table 8. Tabular representation of preference of investment avenues second wave of COVID 19

\begin{tabular}{|l|l|l|}
\hline Investment avenues & No of respondents & Valid Percent \\
\hline Bank deposits & 8 & 6.95 \\
\hline Post office & 7 & 6.08 \\
\hline Mutual Funds & 38 & 33.04 \\
\hline Equity & 34 & 29.56 \\
\hline Gold & 12 & 10.43 \\
\hline Insurance & 16 & 13.91 \\
\hline Total & $\mathbf{1 1 5}$ & \\
\hline
\end{tabular}

\section{Source: Primary Data}

The table no $7 \& 8$ shows the frequency distribution of the sample investor respondents about the preference of the investment avenues in pre and second wave of COVID-19. With the above analysis it is an evident that there is a variation in the preference of the investors with a 9.57 (16.52-6.95) in case of a bank deposits, 8.7 (14.78-6.08) variation for the post office savings. And it is also observed that a 
positive variation in some investment avenues like for Mutual fund 1.74, Equity market 2.61, 3.48 for Gold and 10.44 for insurance. The outbreak of covid-19 for the income factor is not influencing the preference in gold and equity (Khan et al., 2020). This drastic change in investment avenues for the present study sample respondents are due to a huge financial and health crisis during Covid-19. On the basis of this pandemic, most of the investors showed interest in investing in pharmaceutical sector through equity market and health crisis shift the portfolio of the present study investors in Insurance.

Table 9. Descriptive Statistics

\begin{tabular}{|c|c|c|c|c|c|c|c|c|}
\hline \multirow[t]{2}{*}{$\begin{array}{l}\text { Investment } \\
\text { Avenues }\end{array}$} & \multirow[t]{2}{*}{$\mathbf{N}$} & \multirow[t]{2}{*}{$\begin{array}{c}\text { Std. } \\
\text { Deviation }\end{array}$} & \multirow[t]{2}{*}{$\begin{array}{l}\text { Std. } \\
\text { Error }\end{array}$} & & \multicolumn{2}{|c|}{$\begin{array}{l}\text { 95\% Confidence } \\
\text { Interval for } \\
\text { Mean }\end{array}$} & \multirow[t]{2}{*}{ Minimum } & \multirow[t]{2}{*}{ Maximum } \\
\hline & & & & & $\begin{array}{l}\text { Lower } \\
\text { Bound }\end{array}$ & $\begin{array}{l}\text { Upper } \\
\text { Bound }\end{array}$ & & \\
\hline Bank deposits & 8 & 1.00 & .000 & .000 & 1.00 & 1.00 & 1 & 1 \\
\hline Post office & 11 & 1.00 & .000 & .000 & 1.00 & 1.00 & 1 & 1 \\
\hline Mutual funds & 46 & 1.00 & .000 & .000 & 1.00 & 1.00 & 1 & 1 \\
\hline Equity & 31 & 1.55 & .506 & .091 & 1.36 & 1.73 & 1 & 2 \\
\hline Gold & 5 & 2.00 & .000 & .000 & 2.00 & 2.00 & 2 & 2 \\
\hline Insurance & 14 & 3.00 & .000 & .000 & 3.00 & 3.00 & 3 & 3 \\
\hline Total & 115 & 1.43 & .703 & .066 & 1.31 & 1.56 & 1 & 3 \\
\hline \multicolumn{9}{|c|}{ Weighted aspects } \\
\hline Regular returns & 34 & 1.00 & .000 & .000 & 1.00 & 1.00 & 1 & 1 \\
\hline Future security & 26 & 1.00 & .000 & .000 & 1.00 & 1.00 & 1 & 1 \\
\hline Liquidity & 22 & 1.14 & .351 & .075 & .98 & 1.29 & 1 & 2 \\
\hline Children carrier & 17 & 2.00 & .000 & .000 & 2.00 & 2.00 & 2 & 2 \\
\hline Retirement & 2 & 2.00 & .000 & .000 & 2.00 & 2.00 & 2 & 2 \\
\hline Insurance & 11 & 3.00 & .000 & .000 & 3.00 & 3.00 & 3 & 3 \\
\hline Tax benefits & 3 & 3.00 & .000 & .000 & 3.00 & 3.00 & 3 & 3 \\
\hline Total & 115 & 1.43 & .703 & .066 & 1.31 & 1.56 & 1 & 3 \\
\hline \multicolumn{9}{|c|}{ Savings in pre and second wave of COVID-19 } \\
\hline $11 \%-15 \%$ & 79 & 1.392 & .175 & .000 & -1.82 & -.97 & 1 & 1 \\
\hline $16 \%-20 \%$ & 22 & 1.392 & .175 & .000 & .97 & 1.82 & 1 & 2 \\
\hline $21 \%-25 \%$ & 14 & 3.165 & .210 & .000 & 2.65 & 3.62 & 1 & 1 \\
\hline Total & 115 & 5.949 & .56 & .000 & 1.8 & 4.47 & 1 & 1 \\
\hline \multicolumn{9}{|c|}{ Change in portfolio } \\
\hline YES & 36 & 1.00 & .000 & .000 & 1.00 & 1.00 & 1 & 1 \\
\hline $\mathrm{NO}$ & 79 & 1.63 & .771 & .087 & 1.46 & 1.81 & 1 & 3 \\
\hline Total & 115 & 1.43 & .703 & .066 & 1.31 & 1.56 & 1 & 3 \\
\hline
\end{tabular}

Note: $\alpha-{ }^{* *}: \mathrm{p}<0.05$ (2 tailed); S: significant; ns: not significant level of significance at $5 \%$ Source: Primary Data

The present study made an attempt with a sample of 115 investors. The variable investment avenues scores ranges from (1.00 to 1.00) with a mean of 1.00 (bank deposits, post office and mutual fund) with a standard deviation of (0.000), Equity scores range from (1.00 to 3.00) with a mean of (1.55) standard deviation of (0.506), and others Gold and Insurance scores ranges from (2.00 to 3.00) with a mean of $(2.00,3.00)$ and a standard $(0.000)$. The analysis clearly explains the impact of double dip of 
COVID-19 in the preferences of investors to invest based on the savings of the sample investors respondents.

The table explains about the descriptive analysis of the investors' savings during second wave of COVID-19, where the various weighted aspects of the investment avenues score range from (1.00 to 3.00). The weighted aspect of regular return, future security score a mean range of (1.00) with a standard deviation of (0.000), liquidity aspect ranges from (1.00 to 2.00) with a mean (1.14) and a standard deviation of (0.351), children carrier, retirement score range from (2.00 to 3.00) with a mean of (2.00) and standard deviation of (0.000), and the other aspects ranges to (3.00) with a mean of (3.00) and standard deviation of $(0.000)$.

Following to this it depicted the analysis of savings of the investors in pre and second wave of covid-19 were, for $11 \%-15 \%$ and $16 \% 20 \%$ mean score range of (1.00 to 1.00) and (1.00 to 2.00) with a mean of (1.392) and a standard deviation of (.175) and $21 \%-25 \%$ mean score ranges from (1.00 to $1.000)$ with a mean of (3.165) and a standard deviation of (.210), the descriptive analysis of the investors' savings habits with the impact second wave COVID-19, where mean score ranges from (1.00 to 3.00), with a standard deviation of (0.000) and (0.771).

Table 10. Results of the Homogeneity of variance test

\begin{tabular}{|c|c|c|c|c|c|}
\hline & Hypothesis statement & $\begin{array}{l}\text { Levene } \\
\text { Statistic }\end{array}$ & df1 & df2 & Sig. \\
\hline H1A & $\begin{array}{l}\text { Second wave of COVID-19 has an impact on the } \\
\text { preference of the investors in investment }\end{array}$ & 9.924 & 2 & 112 & .000 \\
\hline $\mathrm{H} 2 \mathrm{~A}$ & $\begin{array}{l}\text { COVID-19 second wave has an impact on the } \\
\text { weighted aspects of the investors in investment }\end{array}$ & 12.964 & 6 & 108 & .000 \\
\hline $\mathrm{H} 3 \mathrm{~A}$ & $\begin{array}{l}\text { The savings of the investors differs in constructing } \\
\text { portfolio in first and second wave of COVID-19 }\end{array}$ & 149.858 & 1 & 113 & .000 \\
\hline
\end{tabular}

Note: H1A- statement of hypothesis 1, H2A-statement of hypothesis 2, H3A- statement of hypothesis 3, LS- Levene Statistics for homogeneity test, df- degree of freedom1, , sig- result of the test with the significant values.

To know the assumption that the variance was homogenous, a high priority level of the homogeneity test was conducted with the help of Levene' Statistic.

Hypothesis 1: Analyzing to H1A stated that second wave of COVID-19 has an impact on the preference of the investors in investment. The F-values and significant value for the Levene' test were $(\mathrm{F}(2,112)=$ 9.924), $(\mathrm{p}=0.000)(\mathrm{H} 1 \mathrm{~A})$. With this analysis it is clearly mentioned that the significance values are less than 0.05 , thus the finding reject the null hypothesis.

Hypothesis 2: Followed with this hypothesis, H2A associated that COVID-19 second wave has an impact on the weighted aspects of the investors in investment and the result revealed that F-value and significance value for the Levene's test were $(F(6,108)=12.964),(p=0.000)$. Hence the results illustrated that the significance values are less than 0.05 , thus the results suggests that reject the null hypothesis.

Hypothesis 3: Concerning the hypothesis, H3A reveals that the savings of the investors differs in constructing portfolio in between first and second wave of COVID-19 and the result stated that the Fvalues and significance values for the Levene' test were $(F(1,113)=149.858),(p=0.000)$. Therefore, it is an evident that the significance values are less than 0.005 , will reject the null hypothesis. 
Table 11. Pearson correlation constructs $(n=115)$

\begin{tabular}{|l|r|r|r|}
\hline & $\begin{array}{c}\text { Preference during second } \\
\text { wave of covid 19 }\end{array}$ & $\begin{array}{c}\text { Weighted aspects in } \\
\text { investment avenues }\end{array}$ & $\begin{array}{c}\text { Savings in first and } \\
\text { second wave of covid 19 }\end{array}$ \\
\hline $\begin{array}{l}\text { Preference during } \\
\text { second wave of } \\
\text { covid 19 }\end{array}$ & 1.000 & .918 & .832 \\
\hline $\begin{array}{l}\text { Weighted aspects } \\
\text { in investment } \\
\text { avenues }\end{array}$ & & 1.000 & .908 \\
\hline $\begin{array}{l}\text { Savings in first and } \\
\text { second wave of } \\
\text { covid 19 }\end{array}$ & & & \\
\hline
\end{tabular}

Note: ${ }^{*}: \mathrm{p}<0.05$ (2 tailed); S: significant; ns: not significant.

To determine the consistency of the interrelationship between selected variable such as investment avenue preference during second wave of Covid-19, weighted aspects in Investment Avenue and savings in between first and second wave of Covid-19 Pearson's correlation analysis was used. The present study was accurate, with a coefficient varying from (0.832 to 0.918$)$ for variables. It represents the degree of relationship between the preferences of various investment avenues, savings in constructing the portfolio. With the help of the correlation coefficient statistic shows that preference on various investments avenue had a positive correlation with weighted aspects of investments $(\mathrm{r}=0.918$, $, \mathrm{p}<0.05)$ and a positive relation with savings $(\mathrm{r}=0.832, \mathrm{p}<0.05)$ and the finding were confirmed ( $\mathrm{K}$., 2021), benefits and savings are the main factor and had a moderate positive influence on preference of various investment avenue $(\mathrm{r}=0.908, \mathrm{p}<0.05)$ at $5 \%$ significance level.

Table 12. Result of Analysis of Variance (ANOVA)

\begin{tabular}{|c|c|c|c|c|c|c|}
\hline & & $\begin{array}{c}\text { Sum of } \\
\text { Squares }\end{array}$ & df & $\begin{array}{l}\text { Mean } \\
\text { Square }\end{array}$ & $\mathbf{F}$ & Sig. \\
\hline \multirow{6}{*}{$\begin{array}{l}\text { Preference during } \\
\text { second wave of } \\
\text { COVID } 19\end{array}$} & Between Groups & 134.006 & 2 & 67.003 & 127.789 & .000 \\
\hline & Unweighted & 119.096 & 1 & 119.096 & 227.142 & .000 \\
\hline & Linear term Weighted & 133.460 & 1 & 133.460 & 254.538 & .000 \\
\hline & Deviation & .546 & 1 & .546 & 1.041 & .000 \\
\hline & Within Groups & 58.724 & 112 & .524 & & \\
\hline & Total & 192.730 & 114 & & & \\
\hline \multirow[t]{6}{*}{ Weighted aspects } & Between Groups & 9.906 & 1 & 9.906 & 24.149 & .000 \\
\hline & Unweighted & 9.906 & 1 & 9.906 & 24.149 & .000 \\
\hline & Linear term Weighted & 9.906 & 1 & 9.906 & 24.149 & .000 \\
\hline & Deviation & 6.732 & 1 & 6.732 & 12.647 & .000 \\
\hline & Within Groups & 46.354 & 113 & .410 & & \\
\hline & Total & 56.261 & 114 & & & \\
\hline \multirow{6}{*}{$\begin{array}{l}\text { Savings in first } \\
\text { and second wave } \\
\text { of COVID } 19\end{array}$} & Between Groups & 53.670 & 6 & 8.945 & 372.865 & .000 \\
\hline & Unweighted & 27.271 & 1 & 27.271 & 1136.765 & .000 \\
\hline & Linear term Weighted & 46.371 & 1 & 46.371 & 1932.942 & .000 \\
\hline & Deviation & 7.299 & 5 & 1.460 & 60.850 & .000 \\
\hline & Within Groups & 2.591 & 108 & .024 & & \\
\hline & Total & 56.261 & 114 & & & \\
\hline
\end{tabular}

Note: *.The mean difference is significant at the 0.05 level, df- degree of freedom, MS-mean of Sum of square, F-statistical test.

This section shows the F-Test (Analysis of variance) for 115 sample investors respondents based on the preferred of the investment avenues which influence sample investors to invest. Three variables 
were designed the interrelationship among the study variable like preference in various investment avenues, weighted aspects in investments, and saving.

Results of Hypothesis 1: In the present study H1A, stated that second wave of COVID-19 has an impact on the preference of the investors in investment. The F-value and significance value for the Analysis of variance test were $(\mathrm{F}(2,113)=127.789),(\mathrm{p}=0.000),(\mathrm{H} 1 \mathrm{~A})$. With this analysis it is clearly mentioned that the significance values are less than 0.05 , thus the findings reject the null hypothesis.

Results of Hypothesis 2: With respect to the re entry COVID -19 impact on the preference of the investors to investment. Concerning to the hypothesis H2A, associated that COVID-19 second wave has an impact on the weighted aspects of the investors in investment. The result clearly stated that various aspects of the investor were $(n=35, \mu=29.56)$ are expecting regular return, $(n=26, \mu=22.60)$ are securing for future requirements, $(n=12, \mu=10.43)$ were looking for the insurance benefits. Due to increase in the number of cases in this prolonged crisis, the (IANS, 2020), mandated all general and health insurers to start offering Corona Kavach- an indemnity health based plan, Corona Rakshak- a fixed health insurance benefit to their customers which covers hospital and medical expenses of COVID19 patients. A vast variation observed in the investors' preference, with the digitalization support from the many insurance companies to their clients with better choices and smooth delivery system. Therefore it is an evident with the analysis that F-values and significance values of Analysis of variance test were $(\mathrm{F}(1,113)=24.149),(\mathrm{p}=.000)(\mathrm{H} 2 \mathrm{~A})$ thus findings reject the null hypothesis, that there is a significant difference in the weighted aspects of the various investments avenues in second hit of COVID-19.

Results of Hypothesis 3: The two variables consider under this paper is income level and the savings of the investors in constructing their portfolio during reappear pandemic situation. With this same line H3A, stated that the savings of the investors differs in constructing portfolio in between first and second wave of COVID-19. The F-value and significance value for the Analysis of variance test were $(\mathrm{F}(6,108)=372.865),(\mathrm{p}=0.000),(\mathrm{H} 3 \mathrm{~A})$. The results shows that significance value are less than 0.05 , thus the finding reject the null hypothesis, with respect to income level and the savings of the investors in constructing their portfolio separating first and second wave of Covid-19.

\section{FINDINGS OF THE STUDY}

- The present study has been undertaken with the main objective to find the preference of the investors in various investment avenues in double hit of COVID-19 and its impact on their savings and income level with respect to the salaried employees.

- In the pair of pandemic, many of the salaried employees have realized the importance of the money, savings and its abundance and begin their financial plans.

- Analysis of the present study was done with the help of survey method with 115 sample investors' respondents of Telangana and reveals that 67.82 percent are male respondents and 32.17 percent are female respondents.

- The study revealed about the different kind of investors as aggressive, conservative, balanced and speculative, where majority of the respondents are balanced investors with a valid percent of 45.21 percent and second majority are from conservative of 31.30 valid percent.

- Novel Corona Virus not only caused a huge health damage crisis, economy but also savings habits and income levels of the individuals with a valid percent of 68.69 percent and impact in constructing their portfolio with a valid percent of 74.78 .

- Investing is a chord and passionate activity with the investors' necessities and dreams, but is hold up with the raise of uncertainty puts their financial plans hard with a huge valid variation.

- It is analyzed that there is a significant difference in the preference of the investors in various investment avenues during second wave of Covid-19. 
- The paper also revealed about the there is a significant difference in the weighted aspects of the investments in pre and second wave of Covid-19, and found many of the investors are willing for the insurance policies with the various plans from IRDAI, like Corona Kavach and Corona Rakshak.

- Finally, lockdown has unlocked the savings and FD's.

\section{CONCLUSION}

The present study has made a genuine attempt to analyze the preference of the investors in Mutual Fund and constructing their portfolio with respect to the salaried employees. Most probably investors consider their savings as a path to meet any obligations, and prefer investing with minimum risk that warrant constant and steady returns. The study concludes that many of the investors prefer for secured and regular returns. After the statistical analysis, the investors still prefer to invest in Mutual Fund, equity and insurance also. On the other hand the authors revealed about the facts of the COVID-19 impacts on various investment avenues, savings and income of the investors that due to cut off in pays and jobless, people spending only on the necessity foods, health, education, insurance etc. Due to this health and financial crisis in pandemic situation, investors prefer the safety and health insurances as an important factor while investing. It is very essential and completely needed to save from earn, plan for future benefits and to endure the spending funds. From COVID-19, the entire world taught a good lesson about income and savings that when and where to spend as it is a quite difficult but started habituated. Vaccines building hope in the minds of the people to fight against this COVID-19. Finally, with the help of ayurvedic medicine by Anandaih from Krishnapatnam AP gives people a deep positive breath for the positive COVID-19 patients.

Conceptualization: P. Madhu Kumar Reddy

\section{AUTHOR CONTRIBUTIONS}

Data Curation: P. Madhu Kumar Reddy

Formal Analysis: V S Prasad

Funding Acquisition: P. Madhu Kumar Reddy

Investigation: P. Madhu Kumar Reddy

Methodology: P. Madhu Kumar Reddy

Project Administration: A.Rama Kumar

Resources: P. Madhu Kumar Reddy

Software: P. Madhu Kumar Reddy

Supervision: A.Rama Kumar

Validation: V S Prasad

Visualization: A.Rama Kumar

Writing - Original Draft: V S Prasad

Writing - Review \& Editing: A.Rama Kumar

\section{CONFLICT OF INTEREST STATEMENT}

The authors declare that they have no competing interests.

\section{ACKNOWLEDGEMENT}

All authors contributed equally to the conception and design of the study.

\section{REFERENCES}

Agrawal, N., \& Ashraf, H. (2020, December). COVID-19 Impact on Daily Life (CIDL) Survey. Retrieved from https://www.dvara.com/research/wp-content/uploads/2020/06/COVID-19Impact-on-Daily-Life-CIDL-Survey.pdf 
Afrina, T., Beg, T. H., Zayed, N. M., Hossain, M. S., \& Shahi, S. K. (2020). An analysis of the effects of corona virus (COVID-19) on international financial derivatives market, 2020. Indian Journal of Finance and Banking, 4(2), 93-98. https://doi.org/10.46281/ijfb.v4i2.757

Athira, K., \& Kakkakunnan, M. K. (2020). Impact of Demographic Traits and Personality Traits of Investors on Their Risk-Bearing Capacity: A Study with Special Reference to Investors of Kerala. Indian Journal of Finance and Banking, 4(2), 64-78. https://doi.org/10.46281/ijfb.v4i2.737

Buffett, W. (n.d.). BARBARA FIREDBERG. Retrieved from https://barbarafriedbergpersonalfinance.com/saving-money-advice-warren-buffett/

Chittineni, J. (2020). The Impact of COVID-19 Pandemic on the Relationship between India's Volatility Index and Nifty 50 Returns. Indian Journal of Finance and Banking, 4(2), 58-63. https://doi.org/10.46281/ijfb.v4i2.731

Dhiman, B., \& Raheja, S. (2018). Do personality traits and emotional intelligence of investors determine their risk tolerance?. Management and Labour Studies, 43(1-2), 88-99. https://doi.org/10.1177/0258042X17745184

Graham, B., \& Dodd, D. L. (1996). Security Analysis. In B. G. Dodd, Security Analysis (pp. 1-725). McGraw-Hill. Retrieved from https://scholar.google.co.in/scholar?q=graham+and+dodd+(1934)\&hl=en\&as_sdt=0\&as_vis=1 \&oi=scholart

Gurbaxani, A., \& Gupte, R. (2021). A Study on the Impact of COVID- 19 on Investor Behaviour of. Australasian Accounting,, 15(1), 70-92. https://doi.org/10.14453/aabfj.v15i1.6

IANS. (2020, June 28). MINT. Retrieved from https://www.livemint.com/insurance/news/-coronakavach-corona-rakshak-insurance-policies-on-offer-from-july-10-11593336124657.html

Jain, C. S. (n.d.). A STUDY OF CHANGES IN INDIVIDUAL INCOME, SPENDING \& SAVING PATTERN AS A RESULT OF COVID 19 SITUATION IN INDIA. IMDR. PUNE. Retrieved from https://www.fergusson.edu/upload/document/62118_CASwetaJain(IMDR).pdf

Khan, S., Upadhyaya, C., Gautam, S., \& Natu, P. (2020). A STUDY ON THE IMPACT OF COVID-19 ON THE INVESTMENT PATTERN OF INVESTORS WITH SPECIFIC REFERENCE TO TRADITIONAL INVESTMENT (REAL ESTATE AND GOLD) AND MARKET BASED FINANCIAL PRODUCTS (EQUITIES) IN MUMBAI. European Journal of Molecular \& Clinical Medicine, 7(11), 2020. $\quad$ Retrieved from https://ejmcm.com/pdf_7689_446a3efce1f6994e17ebc62195223808.html

Manoj, M. S., \& Avinash, M. B. (2020). Performance Evaluation Of Mutual Funds Before And During The Outbreak Of Covid-19 Pandemic In India. European Journal of Molecular \& Clinical Medicine, 7(8), 2286-2305. from https://ejmcm.com/pdf_4558_9f87592751702c39037d83cc6e05e995.html

Mushir, N., \& Suryavanshi, R. (2021). Impact of COVID-19 on portfolio allocation decisions of individual investors. Journal of Public Affairs, 21(4), e2649. https://doi.org/10.1002/pa.2649 
Martin, A., Markhvida, M., Hallegatte, S., \& Walsh, B. (2020). Socio-economic impacts of COVID-19 on household consumption and poverty. Economics of disasters and climate change, 4(3), 453479. https://doi.org/10.1007/s41885-020-00070-3

Neill, A. O. (April 1 2021). India: Youth unemployment rate from 1999 to 2020. Retrieved from https://www.statista.com/statistics/812106/youth-unemployment-rate-in-india/

Polisetty, A. (2020, August 3). Indian Mutual Funds during COVID pandemic times. Research Gate, 91-103. Retrieved from https://www.researchgate.net/publication/343389834

Polisetty, A., \& Manda, V. K. (2020, November). Indian Mutual Funds in the times of Covid-19 Introduction. Research Gate, 46-48. doi:10.17605/OSF.IO/6YRDC

Riyazahmed, K. (2021). Investment motives and preferences-An empirical inquiry during COVID-19. Investment Management and Financial Innovations, 18(2), 1-11. https://doi.org/10.21511/imfi.18(2).2021.01

STATISTA. (March 19, 2021). Impact on household income due to the coronavirus (COVID-19) in India from February to April 2020. Retrieved from https://www.statista.com/statistics/1111510/india-coronavirus-impact-on-household-income/

Schembri, L. (2021, March 11). Bank of Canada Banque Do Canda. Retrieved from Bank of Canada: Retrieved from https://www.bis.org/review/r210312a.pdf

Sendilvelu, K., \& Shah, M. D. (2021). A COMPARATIVE STUDY ON INVESTMENT PATTERN OF SELF-EMPLOYED \& START-UP ENTREPRENEURS WITH SPECIAL REFERENCE TO PAN INDIA. Indian Journal of Finance and Banking, 5(2), 62-84. https://doi.org/10.46281/ijfb.v5i2.1025

Srivastava, V. K., \& Kulshrestha, N. (2020, August 3). Portfolio Selection and Performance Evaluation Through Benjamin Graham's Value Investing. Indian Journal of Finance and Banking, 4(2), 1116. https://doi.org/10.46281/ijfb.v4i2.688

THOMAS, T. C., \& RAJENDRAN, G. (n.d.). BB\&K Five-way Model and Investment Behavior. International Journal of Economics and Management, 6(1), 115-127. Retrieved from http://www.ijem.upm.edu.my/vol6no1/bab07.pdf

\section{Copyrights}

Copyright for this article is retained by the author(s), with first publication rights granted to the journal. This is an open-access article distributed under the terms and conditions of the Creative Commons Attribution license (https://creativecommons.org/licenses/by/4.0). 